\title{
The Effects of Entrepreneurship Learning Methods To Learners Entrepreneurship Interest
}

\author{
Herlina Andy Irawan \\ STIE KRIDATAMA BANDUNG \\ Bandung Indonesia \\ herlina@upi.edu
}

\begin{abstract}
The results of this research based on the sports data and students have passed entrepreurship who is learning that the interest they did not grow optimally . Found school tuition who have passed in two years to five years had not previously been many of those who seek to have their own businesses. The limitation of synthesis trouble taken is the learning methods in the classroom and outside of class that is set as variable free and interest of entrepreneurship as variable bound. Research methodology used in this research is a method of quantitative research survey eksplanasi with the approach. Data processing using analysis Pearson Product Poment and Double Correlations. The purpose of this research is to know how big the influence of the learning methods both inside and outside of class against interest of entrepreneurship school tuition. From the results of this study researchers were able to give advice to the teachers field of study marketing and related parties to the students interest of entrepreneurship. The conclusion of this research is the existence of a fairly significant effect of a method of learning in the classroom and outside of the students interest of entrepreneurship.
\end{abstract}

Keywords-The Learning Methods and Entrepreneurship Interest.

\section{INTRODUCTION}

Unemployment is still a serious problem in Indonesia because up to now the number of labor force is inversely proportional to the existing employment opportunities and there is also the possibility of unemployment. Based on the results of the Central Bureau of Statistics the unemployment rate or called Open Unemployment Rate (TPT), which was in August 2013 was 6.25\% (7.39 million people) and now in March 2014 decreased to $6.03 \%$ ( 7.24 million people). Although the figure shows a decline, the government will still minimize unemployment in Indonesia. So the community needs to be increased productivity.

The early research is taken in 2 years back that the graduate of Sangkuriang Vocational High School 1 Cimahi is as much as $55 \%$ work as an employee in the

\footnotetext{
${ }^{1}$ Bruce R.Barringer dan R.Duane Ieland, Entrepreneurship, Pearson Prentice, New Jersey, 2008.
}

institution or factory, 5\% continue to Higher Education, $15 \%$ as a small entrepreneur, 9\% married to be housewives, and $14 \%$ are unemployed without any work. This is due to lack of interest in entrepreneurship of learners.

Based on the above, one way to increase the productivity of the community is by inculcating entrepreneurship interest from an early age to them to not only become job seekers, but as opening jobs for themselves and others.

According to Bruce R. Barringger and R. Duane Ireland (2008),

"Why become an entrepreneurship? The three primary reasons that people becomes entrepreneurs and start their own firms are to be their own boss, pursue their own ideas, and realize financial rewards."

Based on that, entrepreneurship education is considered necessary at all levels of educational units to cultivate or inculcate entrepreneurial mentality in the younger generation, with the hope that after receiving entrepreneurial education in school students will be able to change their mindset about employment. And furthermore learners are expected to no longer minded with orientation to be employees but turned back to oriented looking for employees.

The researcher's review in this thesis focuses on the learning methods held by the school, inside and outside the classroom in the subjects of Entrepreneurship. According to Astamoen (2008) "The need for entrepreneurship education or training (entrepreneurship) for students, the students to be more advanced and later there will be an interest to be entrepreneurs, the small and medium enterprises and students should be given entrepreneurship training." 2 The meaning of training here includes Materials that can be provided in the classroom or outside the classroom. From the word training itself can be interpreted that the provision of entrepreneurial material is also implemented outside the classroom. Furthermore, according to

\footnotetext{
2 Astamoen, M. P, Entrepreneurship Dalam Perspektif Kondisi Bangsa Indonesia, Alfabeta, Bandung, 2008.
} 
Komara (2014) in his book on the method of projectbased learning, suggests that:

"This method is an operational concept of "Production-Based Education" that developed in Vocational High School as an institution that serves to prepare graduates to work in the business world and industry should be able to equip their students with "standard competencies" needed to work in their respective fields." 3

Discussion about the method of project-based learning here researchers took the method of tourism work as imposed by the school where the researchers conducted research. In addition to the work of tourism, learners are equipped with learning out of class, that is by learning to sell directly in the school area.

Furthermore, the basics of researchers take this problem because based on preliminary observations on Vocational High Schol Sangkuriang 1 Cimahi that the cause of unpreparedness students to entrepreneurship caused by low interest in entrepreneurship learners, this can be seen from the attitude:

1. Lack of self-confidence that learners can be seen from the attitude of cheating and imitating the work of others; 2. Not dare to take risks, which is seen from the attitude of students who do not like if given a challenging job;

3. Not creative, this is seen from the lack of active learners in the learning process where still rarely ask learners, and lack of readiness when they come to school; 4. Do not have high achievement motivation, can be seen they just leave school, in class just listen, and go home.Furthermore, if given the task of doing random and often done in school.

The least number of learners who choose to entrepreneurship is also due to their mindset about the entrepreneurial world, according to them plunge into the business world is not the right career choice. They think that for entrepreneurship they will be faced with a situation that is uncertain, full of obstacles, and easily frustrated in the effort to establish a new business.

Based on the background that has been described above it can be formulated some problems that become the focus in this research, that learners are given science or model of learning in the classroom and outside the classroom, then we submit the formulation of the problem is how big the influence of learning methods both in the classroom and outside the class of entrepreneurship interests of learners.

\footnotetext{
${ }^{3}$ Endang Komara, Belajar dan Pembelajaran Interaktif, PT. Refika Aditama Bandung, 2014.

${ }^{4}$ Undang-Undang Republik Indonesia No. 20. Sistem Pendidikan Nasional, Pasal 1 ayat (1), 2013.
}

\section{ENTREPRENEURSHIP EDUCATION}

In the Law of the Republic of Indonesia No. 20 of 2003 on National Education System Article 1 paragraph (1) stating "Education is a conscious and planned effort to create an atmosphere of learning so that students actively develop their potential to have spiritual strength, self-control, personality, intelligence, noble character, and Skills needed himself, society, nation and state ". This national education is based on Pancasila and the Constitution of the Republic of Indonesia and is responsive to the demands of the times." ${ }^{\prime 4}$ National education function to develop the ability and form the character and civilization of dignified nation in order to educate the nation with dignity in order to educate the nation, aims to the development of the potential students to become human beings who believe and piety to God Almighty, noble, healthy, knowledgeable, capable, Creative, independent and become a democratic and responsible citizen.

In the broad context of entrepreneurship education put forward by Rohani (2004) in entrepreneurship education as follows:

"Entrepreneurship education is a kind of education that teaches people to create their own business. Such education is done by: (a) Building faith, soul and spirit, (b) Building and developing a mental attitude and entrepreneurial character, (c) Developing thinking and entrepreneurship, (d) Promoting and developing selfdriving power ) Understand and master the techniques in dealing with risks, competition and a process of cooperation, (f) Understand and master the ability to sell ideas, (g) Have the ability of management or management, and (h) Have certain skills including the mastery of a particular foreign language for the purposes communication." $" 5$

Learning methods

Etymologically, the term method derives from the Greek, ie metodos. It consists of two syllables, metha which means through or through and hodos which means path or way.

As Hamalik (1983) points out, "According to the theory of the science of the soul of power, learning is the effort to train the forces to develop so that they can think, remember, and so on. " 6

The teaching methods, which are planned to be used in describing each of the predefined subjects. Experts present several methods of learning, one of which is Sagala (2006) suggests a number of teaching methods

\footnotetext{
${ }^{5}$ Rohani, A, Pengelolaan Pendidikan. Rineka Cipta, Jakarta, 2004..

${ }^{6}$ Hamalik, O, Belajar dan Kesulitan-Kesulitan Belajar. Tarsito, Bandung, 1983.
} 
that teachers may be able to do with various steps, their goodness and weaknesses, among others as follows: Lecture Method, Question Answer Method Demonstration, Discussion Method, Demonstration Method, Work Tour Method, Group Work Method, Exercise Method, Tasking Method, Experimental Method."7 In this journal the authors will take the lecture method for learning in the classroom and methods of tourism work so that learners are able to understand and analyze the process of buying and selling in the real field.

According to Bruce R. Barringger and R. Duane Ireland (2008) defines entrepreneurship :

"The word entrepreneur derives from the French words entre, meaning "between", and prendre, meaning "to take". The word was originally used to describe people who "take on he risk" between buyers and sellers or who "undertake" a task such as starting a new venture. Inventores and entrepreneurs differ from each other. An inventor creates something new. An entrepreneur assemble and then integrates all the resources needed, the money, the people, the business model, the risk bearing ability to transform the invention into a viable business. "8

Other than that the word entrepreneur comes from the word "wira" and "effort". This means that a person with an entrepreneurial ability has a high mental strength that allows him to jump and slide forward beyond the average ability.

As according to Kasmir (2006) states that the entrepreneurial meaning of people who are courageous take the risk to open a business in various opportunities." 9

Meanwhile, more simply put forward by Suryana (2009) that "entrepreneur is someone has a certain soul and ability in creating and innovating." 10

\section{METHODS}

The research method used in this study is the explanatory survey method is the explanation of research using questionnaires or questionnaires submitted to the respondents. According to Sugiyono (2013), "Survey research is a study conducted on large and small populations, but the data studied is sample data taken from that population." "11

Through this explanation survey method is expected to obtain the necessary data and information in the research and in order to obtain a description of "The

\footnotetext{
${ }^{7}$ Sagala, S, Konsep dan Makna Pembelajaran untuk Membantu Memecahkan Problematika Belajar dan Mengajar, Bandung: CV. AFABETA, 2006.

${ }^{8}$ Bruce R.Barringer dan R.Duane Ieland, Entrepreneurship, Pearson Prentice, New Jersey, 2008.

${ }^{9}$ Kasmir, Kewirausahaan, Jakarta : Rajawali Pers, 2006.
}

Effect of Entrepreneurship Learning Methods to The Learners Entrepreneurship Interest at Sangkuriang Vocational High School 1 Cimahi". Data obtained through measuring instruments in the form of test instruments and questionnaires to be analyzed quantitatively with correlational statistics.

To know the result of research, researcher use some step of statistical data processing by using SPSS 17, that is:(1). Descriptive Analysis. Descriptive analysis is done to know and explain the variables of a situation or situation. In this section we describe the results of research with descriptive method of survey. This method is carried out on the research variables independently without seeing the relationship between variables. (2). Associative Anactivity.Descriptive analysis is basically used to answer the identification of problems posed by this study. The identification of other problems can only be answered by associative analysis, which consists of two steps:

Data Transformation and Classic assumption test. The classical assumption test used in this research are: normality, multicollinearity, heteroscedasticity, and autocorrelation test; as follows:

(1). Data Normality Test.The purpose of the normality test is to test whether in a regression model; Dependent variable, independent variable, or both variables have normal distribution or not. "A good regression model is one that has normal or near-normal data distribution"12 Santosa S (2000). In this case the researcher uses the PPlot Normal Curve Output to test the normality of the data. Shows the spreading dots around the diagonal line and its distribution following the direction of the diagonal line. Thus, the regression model deserves to predict entrepreneurial interest based on input from the independent variables, namely: the learning model in the classroom and outside the classroom.

(2). Multicolinearity Test. This test is useful to identify the existence of correlation between independent variables, namely: Learning Method Variables in the Classroom and Outside Class. If there is a strong correlation between the two variables, then the condition is called "multicollinearity problem". From the test results seen two variables $\mathrm{X}$ has Tolerance and VIF values around the number 1 . Thus, the regression

\footnotetext{
${ }^{10}$ Suryana, Kewirausahaan Pedoman Praktis: Kiat dan Proses Menuju Sukses. Jakarta: Salemba empat, 2009.

${ }^{11}$ Sugiyono, Metode Penelitian Pendidikan, Pendekatan Kuantitatif, Kualitatif, R\&D. Alfabeta, Bandung, 2013. 12 Santosa S, Latihan Statistik SPSS Parametrik, Elex Media Komputindo, Jakarta,2000.
} 
equation used in this study is free from multicollinearity problems.

(3). Automation Test. The autocorrelation test aims to test whether in a linear regression model there is a correlation between the confounding error at one period and the error in the previous period. If there is a correlation, then the condition indicates an autocorrelation problem. "A good regression model is a model independent of the problem of autocorrelation"13 Santosa S (2000). From the results of the study showed that the regression model used in this study has D-W = 1.637 , is between $-2 \mathrm{s.d}+2$. Thus, the regression model used in this study has no autocorrelation problem.

(4). Heteroskedity Test. The purpose of the heteroscedasticity test is to test whether in a regression model there is a variance inequality of the residual obtained from one observation to another. If the residual variance from one observation to another observes remains, then the condition is named as homoscedasticity. However, if the residual variance from one observation to the other is variable / variable then the condition is named as heteroscedasticity. "A good regression model is a regression model that has no heteroscedasticity problem"14 Santosa S (2000). "To detect the presence / absence of heteroscedasticity problems, can be seen from the presence of certain patterns in the scatterplot graph "15 Santosa S (2000). Figure 4.2 shows the absence of a particular pattern, the points spread randomly. That is, there is no heteroskedastisitas on the regression model. Thus, the regression model used in this study deserves to be used to predict entrepreneurship interests of learners.

(5). Multiple Analysis Regression. For regression analysis, it is done partially and simultaneously. Partially regression is done between variables. From the regression results obtained the following discussion that partial regression of learning methods in the classroom with entrepreneurial interest is the number " $R$ " of 0.755 indicates that the relationship or correlation between learning method variables in the class with entrepreneurship interest belong to the category of "strong" because it is in the range $+/-0,51-0,75$. Partial

\footnotetext{
${ }^{13}$ Santosa S, Latihan Statistik SPSS Parametrik, Elex Media Komputindo, Jakarta 2000.

${ }^{14}$ Santosa S, Latihan Statistik SPSS Parametrik, Elex Media Komputindo, Jakarta 2000.

15 Santosa S, Latihan Statistik SPSS Parametrik, Elex Media Komputindo, Jakarta 2000.
}

regression of learning methods outside the classroom with entrepreneurship interest is the coefficient of determination is 0.223 (derived from the product of 0,572 $x$ 0.572). That is, $23.3 \%$ variation that occurs in the entrepreneurship interest variable can be explained by the variations that exist in the variable learning methods outside the classroom. While the rest, amounted to (100$23.3) \%=76.7 \%$ explained by other variables.

\section{RESULT AND DISCUSSION}

This shows that the relationship or correlation between the variables of learning methods outside the classroom with entrepreneurship interest belong to the category "strong enough" because it is in the range $+/$ $0,51-0,75$.

Simultaneous Regression Analysis obtained results: Thus from the results of the study proved that the model of learning in the classroom and outside the class give a significant influence to entrepreneurship interest. Based on the description, it can be seen that "the two methods above have a positive influence on entrepreneurship interest"16 Astamoen (2008). "And the method of learning outside the classroom has a positive and significant impact on entrepreneurship interest. ${ }^{17} \mathrm{dan}^{18}$ And Astamoen (2008) and Komara (2014).

In this discussion will be presented findings of research that has been carried out in accordance with the series of actions taken. Exposure data of these findings preceded by data on the number of students who are at Sangkuriang Vocational High School 1 Cimahi and subsequently researchers collect the processing by using descriptive and associative analysis. From the validity testing is done by grain analysis. To test the validity of each item, the score is in bouts which is correlated with the overall score. In this case the researcher uses a type of construct validity test (construct validity). The construct validity discuss the contents and meaning of a concept and measurement tools that will be used to measure the concept. Correlation of each item of the instrument using the formula Pearson Product Moment Correlation ${ }^{19}$, Sudibyo S. (2005). And the results of the test questions that are variables X1, found two problems are not valid from 10 questions. Then the valid questionnote is 8 points. From the results mengujian $\mathrm{X} 2$ showed that of 10 items the result is valid. The results of

\footnotetext{
${ }^{16}$ Astamoen, M. P. Entrepreneurship Dalam Perspektif Kondisi Bangsa Indonesia. Alfabeta, Bandung, 2008.

${ }^{17}$ Astamoen, M. P. Entrepreneurship Dalam Perspektif Kondisi Bangsa Indonesia. Alfabeta, Bandung, 2008.

${ }^{18}$ Komara, E. (2014). Belajar dan Pembelajaran Interaktif. PT. Refika Aditama, Bandung, 2014.

19 S.Soedibyo, B. (2005). Pengantar Metode Penelitian, Pasim, Bandung, 2005.
} 
questionnaire item of variable $\mathrm{Y}$ as much as 20 items, which is not valid a number of 2 items, while a valid 18 . Thus the items that the next question researchers use is $\mathrm{X} 1=8$ questions, $\mathrm{X} 2=10$ questions, $\mathrm{Y} 1=18$ questions, total totals amounted to 36 Item.

Beside that the test instrument used to test reliability is the Cronbach's alpha test. This test is done to see the consistency of respondents in answering all items of statement. Although these points are independent but when measuring the same concept, these points will be correlated with each other. According to Sekaran in S. Sudibyo (2005) "Alpha Cronbach is a fairly perfect index in assessing the reliability of consistency between items. While the reliability value less than 0.60 indicates that the instrument is less reliable, if the value is within the range of 0.70 then the instrument is categorized as feasible, whereas if the value is more than 0.80 is said to be good." 20

From the test results indicate that the variable $X 1$ reaches a value of 0.734 . Variable $X 2$ reaches value 0,756 , and variable $\mathrm{Y}$ is 0,836 . Of the three figures show Cronbach's Alpha> 0.60, that means the data is reliable.

\section{CONCLUSION}

Based on research on the Effect of Entrepreneurship Learning Methods to the Interest of Entrepreneurship Learners, it can be seen that the entrepreneurship interest of learners is influenced by entrepreneurship learning methods both in the classroom and out of the classroom. The explanation as follows: The first is learning methods of entrepreneurship in the classroom if implemented according to the learning process will significantly affect the interests of entrepreneurship of learners. The second is the entrepreneurial learning method outside the classroom has not been fully significant result, this is because not all students take an active role in learning outside the classroom, so that entrepreneurship interests of learners have not been able to increase significantly. The last is merging of the two learning methods mentioned above there is a significant influence of merging on entrepreneurship interests of learners. So it can be interpreted that to foster interest in entrepreneurship learners are required both methods are mutually supportive.

\section{REFERENCES:}

Alma. (2013). Kewirausahaan Untuk Mahasiswa dan Umum. Bandung: Alfabeta.

Astamoen, M. P. (2008). Entrepreneurship Dalam Perspektif Kondisi Bangsa Indonesia. Bandung: Alfabeta.

\footnotetext{
${ }^{20}$ S.Soedibyo, B. (2005). Pengantar Metode Penelitian, Pasim,
} Bandung, 2005.
Hamalik, O. (1983). Belajar dan Kesulitan-Kesulitan Belajar. Bandung: Tarsito.

Komara, E. (2014). Belajar dan Pembelajaran Interaktif. Bandung: PT. Refika Aditama.

Kasmir, (2006). Kewirausahaan. Jakarta : Rajawali Pers.

Rohani, A. (2004). Pengelolaan Pendidikan. Jakarta: Rineka Cipta.

R. Barringer B dan Ireland D, (2008).

Entrepeuneurship. New Jersey: Pearson Prentice

Hall.

Sagala, S. (2006). Konsep dan Makna Pembelajaran untuk Membantu Memecahkan Problematika Belajar dan Mengajar. Bandung: CV. AFABETA.

S.Soedibyo, B. (2005). Pengantar Metode Penelitian. Bandung: Pasim.

Santosa S, (2000). Latihan Statistik SPSS Parametrik, Elex Media Komputindo, Jakarta: Elex Media Komputindo.

Sugiyono, (2013). Metode Penelitian Pendidikan, Pendekatan Kuantitatif, Kualitatif, $R \& D$. Alfabeta, Bandung: Alfabeta.

Suryana. (2009). Kewirausahaan Pedoman Praktis: Kiat dan Proses Menuju Sukses. Jakarta: Salemba empat.

Undang-Undang Republik Indonesia No. 20 . (2003). Sistem Pendidikan Nasional, Pasal 1 ayat (1). 